\title{
Effects of Bambara Groundnut Supplementation on the Quality of ojojo a Water Yam Based Snacks
}

\author{
Alakali J. S. ${ }^{1}$, Okache T. A. ${ }^{2}$, Agomuo J. K. ${ }^{2}$ \\ ${ }^{1}$ Department of Food Science and Technology, Federal University of Agriculture, Makurdi, Nigeria \\ ${ }^{2}$ Department of Food Science and Technology, Federal University Dutsinma, Katsina, Nigeria
}

Email address:

tokache@fudutsinma.edu.ng (Okache T. A.)

\section{To cite this article:}

Alakali J. S., Okache T. A., Agomuo J. K. Effects of Bambara Groundnut Supplementation on the Quality of ojojo a Water Yam Based Snacks. International Journal of Nutrition and Food Sciences. Vol. 5, No. 6, 2016, pp. 422-428. doi: 10.11648/j.ijnfs.20160506.18

Received: October 6, 2016; Accepted: October 20, 2016; Published: November 23, 2016

\begin{abstract}
The aim of this study is to determine effects of bambara groundnut supplementation on the quality of ojojoa water yam based snacks. In this study, ojojo a water yam based food was prepared, with supplementation of bambara groundnut in the ratios of (100:0), (90:10), (80:20) and (70:30). These products were analyzed for proximate composition, amino acid content, and sensory attributes. Results showed that, the protein content of ojojo increased significantly $(P \leq 0.05)$ with increase in bambara groundnut supplementation from $5.42 \%$ in $(100: 0)$ to $7.92 \%$ in the $(70: 30)$ water yam-bambara groundnut blends. There was significant increase $(P \leq 0.05)$ in essential and non-essential amino acids. Sensory quality attributes of $(100: 0)$ water yam-bambara groundnut blended ojojo had the highest preference in terms of appearance, (80:20) had the highest in terms of taste and (70:30) was the most acceptable in terms of sponginess, flavour, and overall acceptability. The study therefore suggests that supplementation of water yam based ojojo with bambara groundnut improves the protein content and improves the organoleptic properties of ojojo as 70:30 water yam-bamabara groundnut blend was the most preferred. Hence, the supplementation of water yam based ojojo should be encouraged as it offers better chemical qualities and sensory attributes.
\end{abstract}

Keywords: Bambara Groundnut, ojojo, Proximate Composition, Sensory Evaluation, Supplementation, Water Yam

\section{Introduction}

Ojojo is a fried food product, produced from water yam. It is prepared traditionally by grating edible portions of water yam then adding salt and spices such as onion and pepper. It is then mixed thoroughly, scooped with spoon and fried in hot oil, which gives it a striking resemblance with akara balls. Fried foods are tasty and popular around the world. One of the main reasons for this popularity is the "textural dichotomy of the food; dry and crispy crust, tender inside" [1]. Ojojo (fried water-yam balls) is a delicacy most popular among the Ijebu people of south-west Nigeria. Although it was not popular amongst other tribes in Nigeria, today ojojo is consumed in most of the southern parts of Nigeria.

Water yam (Dioscoreaalata), a climbing plant with glabrous leaves and twining stems which coil readily around a stake, is a highly economical yam species [2]. Dioscoreaalata has been suggested to possess potential for increased consumer demand due to its low sugar content, an important factor for diabetic patients. It is called Agbo in Tiv and Ewura in Yoruba land. It is the main staple food in Ijebu area - Western Nigeria. Discoreaalata is also known for its high nutritional content, with crude protein content of $7.4 \%$, starch content of $75-84 \%$, and vitamin $\mathrm{C}$ content ranging from 13.0 to $24.7 \mathrm{mg} / 100 \mathrm{~g}$ [3]. The flesh of the tuber ranges in colour from white to purplish [4]. The texture of its flesh is usually not as firm as that of white yam and less suitable than other species for the preparation of the most popular food products from yam ( $f u f u$ and pounded yam especially) in the West Africa region.

Ojojo produced from water yam is low in protein, hence the need to supplement with bambara groundnut, a protein rich legume. Bambara groundnut (Vigna subterranean), is called Gurjiya or Kwaruru in Hausa, Okpa in Ibo and Epa-kuta in Yoruba, Igbol-ahi in Tiv parts of Nigeria. It originates from West Africa and is cultivated in drier tropical Africa. Vigna subterranean grows well where groundnut does not [5]. It is cultivated primarily as human food, for its seeds. In Africa, it is the third eaten legume after groundnut and cowpea [6]. On dry 
basis, it consists of $51-70 \%$ carbohydrate, $6-12 \%$ moisture, 18.0 - $24.0 \%$ protein (with high lysine and methionine content), $3.0-5.0 \%$ ash, $5.0-7.0 \%$ fat, and $5.0-12.0 \%$ fiber. The energy content is $367-414 \mathrm{~kJ}$ per $100 \mathrm{~g}$ seed, a value that is higher than the energy content of several other pulses [7]. Bambara groundnut can contribute positively to food security and help to alleviate nutritional problems though; it has been classified by [8] as an underutilized crop and is only receiving more attention in the recent past.

This work is set to improve the nutritional value of ojojo traditionally produced from water yam with high carbohydrate content by supplementing with bambara groundnut with high protein content to produce a more nutritious ojojo.

\section{Materials and Methods}

\subsection{Raw Materials}

Water yam (Dioscoreaalata) and bambara groundnut (Vigna subterranean) were purchased from Wurukum market in Makurdi, Benue state. The chemicals and equipment/facilities used were obtained from food processing laboratory of Institute for Agricultural Research, Samaru, Kaduna.

\subsection{Sample Preparation}

The water yam tubers were processed using the traditional method of processing ojojo which involves peeling, washing, slicing into cubes and grating with a grater of $2 \mathrm{~mm}$ pore size. Bambara groundnut seeds were processed using modified method described by [9] which involve sorting to remove all foreign materials such as dirt, small branches and immature seeds and then cleaned by washing with water to remove dust. About 200 grams of clean seeds were soaked in cold water for 2 hours, after which it was dehulled using plate mill with $6 \mathrm{~mm}$ clearance between the plates and then wet milled into paste. The water yam and bambara groundnut samples were mixed at the ratios of 100:0, 90:10, 80:20 and 70:30 respectively. Paste from the $100 \%$ water yam served as the control sample.

\subsection{Preparation of Ojojo}

The paste for ojojo preparation was made by adopting standardized recipe for ojojo preparation by [10] with modifications. About $5 \mathrm{~g}$ of chopped fresh pepper, $4 \mathrm{~g}$ of chopped onions, $0.1 \mathrm{~g}$ mono sodium glutamate seasoning, and $0.1 \mathrm{~g}$ salt was added to $200 \mathrm{~g}$ of the paste. The hand food blender was used to beat the mixture thoroughly. The mixture was then scooped with a spoon of volume $40 \mathrm{ml}$ and dispensed into a frying pot of height $8 \mathrm{~cm}$ and radius $7.5 \mathrm{~cm}$ containing 1.0 liter of hot vegetable cooking oil (refined palm olein) to deep fry for 5 minutes. It was then drained and allowed to cool.

\subsection{Proximate Analysis}

\subsubsection{Moisture Content}

Moisture content was determined using Association of
Official Analytical Chemist [11]. About 5g of each sample was weighed into Petri dishes of a known weight. It was then dried in the oven at $105 \pm 1{ }^{\circ} \mathrm{C}$ for 4 hours. The samples were cooled in desiccators and weighed. The moisture content was calculated as follows:

$$
\text { Percentage moisture content }=\mathrm{x} 100
$$

$\mathrm{W}=$ Initial weight of food before drying.

\subsubsection{Ash Content}

Ash content was determined using the AOAC method [11]. About $5 \mathrm{~g}$ of each sample was weighed into crucibles in duplicate, and then the sample was ashed in a muffle furnace at $550^{\circ} \mathrm{C}$ until a light grey ash was observed and a constant weight obtained. The sample was cooled in the dedicator to avoid absorption of moisture and weighed to obtain ash content.

$$
\text { Ash content }=\times 100
$$

\subsubsection{Fat Content}

Fat content was determined using the AOAC method [11]. About $10 \mathrm{~g}$ of each sample was weighed on chemical balance and wrapped in a filter paper. It was then placed in an extraction thimble. Extractor was cleaned, dried in an oven, and cooled in the desiccator before weighing. Then $25 \mathrm{ml}$ of petroleum was measured into the flask and the fat content was extracted with this solvent. After extraction, the solvent was evaporated by drying in the oven. The flask and its contents were then cooled in a desiccator and weighed fat content. The percentage fat content was calculated as follows:

$$
\text { Percentage of total fat content }=\mathrm{x} 100
$$

\subsubsection{Crude Fibre}

Crude fibre was determined using the AOAC method [11]. About $5 \mathrm{~g}$ of each sample was weighed into a $500 \mathrm{ml}$ Erlenmeyer flask and $100 \mathrm{ml}$ of TCA digestion reagent was added. It was then brought to boiling and refluxed for exactly 40 minutes counting from the start of boiling. The flask was removed from the heater, cooled a little, and filtered through a $15.0 \mathrm{~cm}$ No.4 Whatsman paper. The residue was washed with hot water stirred once with a spatula and transferred to a porcelain dish. The sample was dried overnight at $105^{\circ} \mathrm{C}$. After drying it was transferred to a desiccator and weighed $\mathrm{W}_{1}$ when cool. It was ashed in muffle furnace at $500^{\circ} \mathrm{C}$ for 6 hours; allowed to cool and reweighed $\mathrm{W}_{2}$.

\section{Percentage crude fibre $=\mathrm{x} 100$}

$\mathrm{W}_{1}=$ Weight of crucible + fiber + ash

$\mathrm{W}_{2}=$ Weight of crucible + ash

$\mathrm{W}_{0}=$ Dry weight of food sample

\subsubsection{Protein Content}

The protein content determination was carried out using a micro-Kjedhal method [11], which consist of net digestion, distillation, and titration. The protein content was determined 
by weighing $3 \mathrm{~g}$ of sample into a boiling tube that contained $25 \mathrm{ml}$ concentrated sulphuric acid and one catalyst tablet containing $5 \mathrm{~g} \mathrm{~K}_{2} \mathrm{SO}_{4}, 0.15 \mathrm{~g}, \mathrm{CuSO}_{4}$ and $0.15 \mathrm{~g} \mathrm{TiO}_{2}$. Tubes were heated at low temperature for digestion to take place. The digestion was diluted with $100 \mathrm{ml}$ distilled water, $10 \mathrm{ml}$ of $40 \%$ $\mathrm{NaOH}$, and $5 \mathrm{ml} \mathrm{Na}_{2} \mathrm{~S}_{2} \mathrm{O}_{3}$, anti-bumping agent was added, and then the sample was diluted off into $10 \mathrm{ml}$ of boric acid

The $\mathrm{NH}_{4}$ content in the distillate was determined by titrating with $0.1 \mathrm{~N}$ standard HCL using a $25 \mathrm{ml}$ burette. A blank was prepared by omitting the sample. The protein value obtained was multiplied by a conversion factor, and the result was expressed as the amount of crude protein.

$\%$ crude protein $=$ Actual titre value - titre of blank $\times 0.1 \mathrm{~N}$ HCL x 0.014 x conversion factor $\mathrm{x} 100$ weight of sample.

\subsubsection{Total Carbohydrate Content}

Using the method of [12], total carbohydrate was determined by difference between 100 and the total sum of the percentage of fat, moisture, ash, crude fibre and protein content.

\subsection{Amino Acid Profile}

Qualitative assessment of the essential amino acid composition of ojojo was carried out by ion-exchange chromatograghy [13] using the automatic Technical Sequential Mutlti-sample amino acid analyzer (TSM, model DANA 0209). Amino acid values were obtained from the integrator and expressed as percentages of the total protein. The amino acid scores were calculated from FAO reference values using the formula:

Amino acid Scores $=$ TSM values $/$ FAO standards $\mathrm{x} 100$

\subsection{Sensory Analysis}

The sensory evaluation of the products was performed using a 9-point hedonic scale ranking $1-9$, where $1=$ extremely dislike and 9= extremely like. The ojojos amples were coded and presented to a ten-member semi-trained panel of judges chosen from the food processing laboratory of Institute for Agricultural Research, Samaru, Zaria. The panelists assessed the products for flavour, sponginess, appearance, taste, and overall acceptability as described by [14].

\subsection{Statistical Analysis}

Data were analyzed using analysis of variance ANOVA and Duncan multiple comparison test to test significant differences between means $p<0.05$. Data analysis was done using Statistical Package for Social Science SPSS version 20.0 (SPSS, 1993).

\section{Results and Discussion}

\subsection{Proximate Composition of Water Yam Based "ojojo" Supplemented with Bambara Groundnut}

The proximate composition of "ojojo" samples produced from water yam-bambara groundnut blends in the ratios of 100:0, 90:10, 80:20, and 70:30 were determined and presented in Table 1. The moisture content was $34.97 \%$, $34.97 \%, 34.84 \%$ and $34.14 \%$ respectively. Ash content was $1.40 \%, 2.05 \%, 2.17 \%$ and $2.25 \%$ respectively. Fat content was $22.96 \%, 25.60 \%, 25.60 \%$ and $26.14 \%$ respectively. The protein content was $5.42 \%, 7.00 \%, 7.43 \%$ and $7.92 \%$ respectively. Fibre content was $2.16 \%, 3.32 \%, 3.61 \%$ and $4.41 \%$. Carbohydrate content was $32.69 \%, 27.07 \%, 26.45 \%$ and $24.99 \%$ respectively.

The moisture content was high but values were low when compared to those reported by [10]. Sample with $100 \%$ water yam (control) had the highest moisture content of $34.97 \%$, while sample with $30 \%$ bambara groundnut inclusion had the least mean moisture content of $34.14 \%$. However, there was no significant difference between the control and sample with $10 \%$ bambara groundnut supplementation at $\mathrm{p} \leq 0.05$ level of significance. A decrease in moisture content was observed $(11.7-9.6 \%)$ by [15] as the proportion of bambara groundnut increases from $0-30 \%$ in "ofada" rice. [16]also reported decrease in moisture content of akara as a result of increase in protein form increased soybean supplementation. Protein has been reported to have some functional attributes such as water sorption, viscousity, elasticity, foamability, foam stability and fibre formation which affect moisture content $[17,18]$ The decrease in moisture level with increase in the level of supplementation was suggested to be an indication of increase in storage ability as high moisture content in food has been shown to encourage microbial growth [19]. However the relatively high moisture content ofojojo samples suggests that they may be liable to microbial spoilage during storage and have short shelf life.

The high ash content of samples could be an indication of increase in the principal mineral content which could be of vital importance to the body [20]. Ash content increased with increase in the supplementation with bambara groundnut. Sample prepared from $100 \%$ water yam had the least mean ash content of $1.40 \%$ and it is significantly different from other samples at $\mathrm{P} \leq 0.05$ level of significance. Ojojo sample with $30 \%$ bambara groundnut substitution had the highest mean ash content of $2.25 \%$. The increase in ash content could be due to the added bambara groundnut which has been noted to be relatively high in ash of $3.16 \%$ [21] than the water yam which is $2.25 \%$ [2]. Similar findings where bambara groundnut was supplemented showed improvement in ash content [22].

Dietary fat functions in the increase of palatability of food by absorbing and retaining flavours [23]. Fat is important for providing energy for the body, storing energy for later use, insulating and protecting the body and transporting fat soluble vitamins [24]. Fat content increased upon bambara groundnut addition and values were higher than those reported by [10]. The high fat content could be because bambara groundnut comparatively has more fat $(5.80 \%)$ as reported by [21] than water yam $(0.75-1.10 \%)$ as reported by [2]. This is evident in the control $(100 \%$ water yam) which had the least mean fat content of $22.96 \%$ compared with ojojo sample with $30 \%$ bambara supplementation which had the highest mean fat content of $26.14 \%$. [15] reported 
increase in fat content in "ofada" rice from 4.80-6.10\% with bambara groundnut substitution of from $0-30 \%$. Similarly, fat increase was observed by [22] as fat content increased from $3.0-4.8 \%$ with increase in percentage $(0-25 \%)$ of bambara groundnut flour in "acha" based "fura". The relative increase in fat content could improve the energy level of the consumer as it has been known that one gram of fat or oil will yield about $368 \mathrm{KJ} / \mathrm{g}$ Kcal of energy when oxidized in the body [25].

Protein is needed for growth, maintenance and regulation of the body process. Increased protein content indicates that the supplementation of water yam with bambara groundnut would greatly improve the nutritional quality of "ojojo" produced. This could obviously be due to the significant quality of protein in bambara groundnut seeds. Bambara groundnut contains substantial high level of crude protein and it could be an inexpensive source [21]. Several workers $[26,27]$ have examined the biochemical composition of the seed to contain $19 \%$ protein on an average. [2] reported that water yam contains averagely $6.7 \%$ crude protein on a dry weight basis. The proteins in bambara groundnut will complement those of the water yam and thus improve the nutritional quality. The control sample (100\% water yam) had the least mean protein content $5.42 \%$ while sample with $30 \%$ bambara groundnut supplementation had the highest protein content of $7.92 \%$. However there was a significant difference between all the samples at $\mathrm{P} \leq 0.05$ level of significance. This finding is in support with the research work reported by [15] that showed that fortifying "ofada" rice flour with bambara groundnut flour resulted in considerable improvement in the protein content of the flour and other mineral elements. Similarly, [28] concluded that the nutritional composition of cooking banana can be enhanced through fermented bambara groundnut flour supplementation. [29]reported an increase in the protein content with corresponding increase in the proportion of bambara groundnut flour supplementation in biscuit production from cassava-wheat-bambara groundnut flour blend. [30] also reported increase in protein content with corresponding increase in soy flour supplementation in yam flour. [10] reported that the inclusion of cowpea flour significantly increased the protein content of cocoyam based "ojojo". However findings from this research, shows that the values of crude protein are by far lower than the $15 \%$ minimum protein content recommended by [31].

The indigestible component of plant material, which include cellulose, hemicellulose, pectin, lignin and other peptic materials are referred to collectively as dietary fiber. The fiber content of "ojojo" showed significant increase with increase in the percentage of bambara groundnut substitution. Ojojo sample prepared from $100 \%$ water yam had the least fibre content of $2.61 \%$ while sample with $30 \%$ bambara groundnut inclusion had the highest fibre content of $4.41 \%$. There was however significant difference between all the samples at $\mathrm{P} \leq 0.05$ level of significance. This increase could be as a result of high fibre content of bambara groundnut of $4.5 \%$ reported by [21] and $6.85 \%$ reported by Abdulsalamiet al. (2010). Similar results was observed by [15] as fiber content of "ofada" rice increased from (1.1-1.6\%) with increase in bambara groundnut supplementation up to $30 \%$.

The carbohydrate content decreased with increased in bambara groundnut content and this was expected. Sample with $30 \%$ bambara groundnut supplementation had the least mean carbohydrate content of $24.99 \%$ while the control (100\% water yam) had the highest mean value of $32.69 \%$. However, there was significant difference between all the samples at $\mathrm{P} \leq 0.05$ level of significance. Similar observations were made by other researches such as $[15,22]$. The decrease could be attributed to the water yam which was reported to contain $81.53-87.64 \%$ [2] while bambara groundnut contains relatively lower carbohydrate $55.00 \%$ (Oyeleke et al., 2012), and $51.96 \%$ by [32].

\subsection{Amino Acid Composition of Water Yam Based "ojojo" Supplemented with Bambara Groundnut}

The result of essential, non-essential amino acid composition and amino acid scores of ojojo samples are presented in Tables 2, and 3. The results showed that the values of amino acids increased in ojojo preparation with increase in the level of bambara groundnut supplementation. Similar trend was reflected in the amino acid scores of the various amino acids (Table 3 ). All the essential amino acids and nonessential amino acids increased in quantity with supplementation with bambara groundnut in the samples. This could be due to the fact that bambara groundnut has comparatively higher protein content $(18-24 \%)$ on a dry weight basis with high lysine and methione [7, 33], than water yam with lesser protein content of $6.7 \%$ [2]. According to [34], tuber crops are poor in sulphur containing amino acids. These findings of this work are of great nutritional significance since these amino acids in water yam that are limiting were boosted. Generally, amino acid scores for 70:30 water yam-bambara groundnut blended ojojo were better than the others. Similar findings were observed by [35], where distiller's spent grain was used to improve the amino acid content of water yam. Therefore, the purpose of supplementation of water yam with bambara groundnut has been achieved, since this can also be used to improve the amino acid content of ojojo.

\subsection{Sensory Evaluation on Water Yam Based "ojojo" Supplemented with Bambara Groundnut}

The results of the sensory evaluation on "ojojo" samples are as shown in Table 4. Sensory attributes such as appearance, flavour, taste, sponginess and overall acceptability of each these samples were; samples from $100 \%$ water yam had $7.60,5.90,6.30,3.5$ and 5.55 respectively. Samples from (90:10) water yam-bambara groundnut blend had 7.40, 7.50, 6.70, 3.70 and 6.70 respectively. Samples from (80:20) water yam-bambara groundnut blend was 7.05, 7.25, 7.35, 3.80 and 7.80 respectively and samples from (70:30) had 7.50, 7.60, 7.30, 4.10 and 8.10 respectively.

The control (100:0) water yam-bambara groundnut blend 
was the most acceptable in terms of appearance with mean value of 7.60, while sample of $(80: 20)$ had the least acceptable appearance with a mean value of 7.05. The colour of the ojojo samples changed from cream to golden brown colour. This observation was in contrast to those of [36] who reported the colours to be lighter with supplementation with soy beans. This variation in colours could be as a result of the difference in processing in that the authors used flour and fresh paste was used in this work. There was no significant difference between the control sample and all the other samples at $\mathrm{P} \leq 0.05$ level of significance in terms of appearance.

Sample of (70:30) water yam-bambara groundnut blend had the most acceptable flavour with a mean value of 7.60, while the control (100:0) had the least acceptable flavour with a mean value of 5.90. The control was however significantly different from other samples at $\mathrm{P} \leq 0.05$ level of significance. Sample of (80:20) water yam-bambara groundnut blend had the most acceptable taste with mean value of 7.35, while the control (100:0) had the least value of 6.30. However, sample of $(80: 20)$ was not significantly different from sample of $(70: 30)$ and the control was not significantly different from sample (90:10) water yambambara groundnut blend at $\mathrm{P} \leq 0.05$ level of significance. Sample of (70:30) water yam-bambara groundnut blend had the most acceptable crumb sponginess of 4.10 , while the control had the least value of 3.50. There was however no significant difference between the control and sample of (90:10) water yam-bambara groundnut blend at $\mathrm{P} \leq 0.05$ level of significance. In general, sample of (70:30) water yambambara groundnut had the highest mean value of overall acceptability of 8.10 , whereas the control (100:0) had the least mean value for overall acceptability of 5.55. There was however, no significant difference between samples (80:20) and (70:30) water yam-bambara groundnut blends at $\mathrm{P} \leq 0.05$ level of significance.

From this research, it was observed that the inclusion of bambara groundnut to water yam helped to improve the organoleptic properties of "ojojo". Similar findings were reported by $[37,38]$ were attributed to the flavour impacted by bambara groundnut and soybean respectively. Although, the control, 100\% water yam "ojojo" had the most preferred appearance, sample of (70:30) was more acceptable in terms of flavour, taste, sponginess and over all acceptability. Hence this improvement could be attributed to the sensory characteristics impacted by bambara groundnut.

\section{Conclusion}

This work has shown that there is improvement in the chemical properties of ojojo, through the use of bambara groundnut supplementation, as it offers higher percentages of protein, crude fiber, ash and fat content. There was significant increase in the quality of the essential and nonessential amino acids, thus supplementing the amino acids that are limiting in water yam. The work shows that supplementation also improves the sensory attributes of ojojo in terms of crust sponginess, flavour, taste and general acceptability.

\section{Recommendations}

This work has shown that ojojo with $30 \%$ bambara groundnut supplementation was the best as it offers a better nutrient and sensory properties hence, the blend should be adopted to produce more nutritious ojojo.

Table 1. Proximate composition of water yam based "ojojo" supplemented with bambara groundnut (\%).

\begin{tabular}{llllll}
\hline Parameter & Ojojo & \multicolumn{1}{l}{ LSD } \\
\hline WY & $\mathbf{1 0 0}$ & $\mathbf{9 0}$ & $\mathbf{8 0}$ & $\mathbf{7 0}$ & \\
\hline BGN & $\mathbf{0}$ & $\mathbf{1 0}$ & $\mathbf{2 0}$ & $\mathbf{3 0}$ & \\
\hline Moisture & $34.97^{\mathrm{a}}$ & $34.97^{\mathrm{a}}$ & $34.84^{\mathrm{b}}$ & $34.14^{\mathrm{c}}$ & 0.13 \\
Ash & $1.40^{\mathrm{b}}$ & $2.05^{\mathrm{a}}$ & $2.17^{\mathrm{a}}$ & $2.25^{\mathrm{a}}$ & 0.65 \\
Fat & $22.96^{\mathrm{c}}$ & $25.60^{\mathrm{b}}$ & $25.60^{\mathrm{b}}$ & $26.14^{\mathrm{a}}$ & 0.54 \\
Protein & $5.42^{\mathrm{d}}$ & $7.00^{\mathrm{c}}$ & $7.43^{\mathrm{b}}$ & $7.92^{\mathrm{a}}$ & 0.43 \\
Fiber & $2.61^{\mathrm{d}}$ & $3.32^{\mathrm{c}}$ & $3.61^{\mathrm{b}}$ & $4.41^{\mathrm{a}}$ & 0.29 \\
Carbohydrate & $32.69^{\mathrm{a}}$ & $27.07^{\mathrm{b}}$ & $26.45^{\mathrm{c}}$ & $24.99^{\mathrm{d}}$ & 0.62 \\
\hline
\end{tabular}

Values are means of duplicate determinations. Mean values along the same rows with different superscripts are significantly different $(\mathrm{P} \leq 0.05)$.

$\mathrm{WY}=$ Water yam, $\mathrm{BGN}=$ Bambara groundnut, $\mathrm{LSD}=$ least significant difference.

Table 2. Essential amino acid (EAA) and nonessential amino acid (NEAA) composition of water yam based "ojojo" supplemented with bambara groundnut. (g/100g).

\begin{tabular}{|c|c|c|c|c|c|}
\hline EEA & Ojojo & & & & FAO \\
\hline WY & 100 & 90 & 80 & 70 & \\
\hline BGN & $\mathbf{0}$ & 10 & 20 & 30 & \\
\hline Lysine* & 0.24 & 0.51 & 0.77 & 1.04 & 4.2 \\
\hline Threonine* & 0.24 & 0.44 & 0.63 & 0.83 & 2.6 \\
\hline Valine* & 0.26 & 0.55 & 0.85 & 1.14 & 42 \\
\hline Methionine* & 0.11 & 0.3 & 0.49 & 0.68 & 2.2 \\
\hline Isoleucine* & 0.23 & 0.53 & 0.82 & 1.12 & 4.2 \\
\hline Leucine* & 0.42 & 0.92 & 1.82 & 1.9 & 4.8 \\
\hline Tryptophan* & 0.1 & 0.39 & 0.68 & 0.97 & 1.4 \\
\hline $\begin{array}{l}\text { Phenylalanine } \\
*\end{array}$ & 0.33 & 0.67 & 1 & 1.34 & 2.8 \\
\hline Histidine* & 0.28 & 0.43 & 0.58 & 0.74 & 2.4 \\
\hline Arginine* & 0.48 & 0.81 & 1.14 & 1.48 & 2 \\
\hline Cysteine & 0.46 & 0.47 & 0.48 & 0.57 & \\
\hline Tryosine & 0.26 & 0.54 & 0.83 & 1.11 & \\
\hline Aspartic acid & 0.5 & 0.95 & 1.14 & 1.85 & \\
\hline Glutamine & 0.92 & 2.48 & 4.04 & 5.59 & \\
\hline Proline & 0.27 & 0.56 & 0.86 & 1.15 & \\
\hline Glycine & 0.24 & 0.52 & 0.85 & 1.13 & \\
\hline Alanine & 0.29 & 0.57 & 0.85 & 1.13 & \\
\hline Serine & 0.42 & 0.67 & 0.92 & 1.16 & \\
\hline
\end{tabular}

Amino acids with asterisks are the essential amino acids, WY= Water yam, $\mathrm{BGN}=$ Bambara groundnut. 
Table 3. Amino acid scores of water yam based "ojojo" supplemented with bambara groundnut. (\%).

\begin{tabular}{lllll}
\hline EEA & Ojojo & & & \\
\hline WY & $\mathbf{1 0 0}$ & $\mathbf{9 0}$ & $\mathbf{8 0}$ & $\mathbf{7 0}$ \\
\hline BGN & $\mathbf{0}$ & $\mathbf{1 0}$ & $\mathbf{2 0}$ & $\mathbf{3 0}$ \\
\hline Lysine & 5.71 & 12.14 & 18.33 & 24.76 \\
Threonine & 9.23 & 16.92 & 24.23 & 31.92 \\
Valine & 6.19 & 13.1 & 20.24 & 27.14 \\
Methionine & 5 & 13.64 & 22.27 & 30.9 \\
Isoleucine & 5.48 & 12.62 & 19.52 & 26.67 \\
Leucine & 8.75 & 19.17 & 29.58 & 39.58 \\
Tryptophan & 7.14 & 27.86 & 48.57 & 69.29 \\
Phenylalanine & 11.79 & 23.93 & 35.71 & 47.85 \\
Histidine & 11.67 & 17.92 & 24.17 & 30.83 \\
Arginine & 24 & 40.5 & 57 & 74 \\
\hline
\end{tabular}

$\mathrm{WY}=$ Water yam, $\mathrm{BGN}=$ Bambara groundnut

Table 4. Sensory attributes of water yam based "ojojo" supplemented with bambara groundnut.

\begin{tabular}{llllll}
\hline Attributes & \multicolumn{3}{c}{ Ojojo } & \multicolumn{2}{l}{ LSD } \\
\hline & WY & $\mathbf{1 0 0}$ & $\mathbf{9 0}$ & $\mathbf{8 0}$ & $\mathbf{7 0}$ \\
\hline & BGN & $\mathbf{0}$ & $\mathbf{1 0}$ & $\mathbf{2 0}$ & $\mathbf{3 0}$ \\
\hline Appearance & $7.60^{\mathrm{a}}$ & $7.40^{\mathrm{a}}$ & $7.05^{\mathrm{a}}$ & $7.50^{\mathrm{a}}$ & 0.1 \\
Flavour & $5.90^{\mathrm{b}}$ & $7.50^{\mathrm{a}}$ & $7.25^{\mathrm{c}}$ & $7.60^{\mathrm{a}}$ & 1.6 \\
Taste & $6.30^{\mathrm{b}}$ & $6.70^{\mathrm{b}}$ & $7.35^{\mathrm{a}}$ & $7.30^{\mathrm{a}}$ & 0.6 \\
Sponginess & $3.50^{\mathrm{b}}$ & $3.70^{\mathrm{b}}$ & $3.80^{\mathrm{ab}}$ & $4.10^{\mathrm{a}}$ & 0.4 \\
Overall & $5.55^{\mathrm{c}}$ & $6.70^{\mathrm{b}}$ & $7.08^{\mathrm{a}}$ & $8.10^{\mathrm{a}}$ & 1.1 \\
acceptability & & & & & \\
\hline
\end{tabular}

Mean values along the same row with different superscripts are significantly different (P 0.05)

$\mathrm{WY}=$ Water yam, $\mathrm{BGN}=$ Bambara groundnut, $\mathrm{LSD}=$ least significant difference.

\section{References}

[1] Mellema, M. (2003). Mechanism and reduction of fat uptake in deep-fat fried foods. Food Science Technology. 14:364-373.

[2] Udensi, E. A., Oselebe, H. O. and Onuoha, A. U. (2010). Antinutritional assessment of D. alata varieties. Pakistan Journal of Nutrition 9: 179-181.

[3] Osagie, A. U. (1992). The yam tuber in storage. Postharvest Research Unit, University of Benin, Benin City, pp: 33-84.

[4] FAO. (1994). Tropical Root and Tuber Crops. In: Production, Perspectives and future Prospects. Onwueme, I. C. and Charles, W. B. (eds.), FAO Plant Production and Protection Paper 126, Rome, Italy.

[5] Brink, M., Ramolemana, G. M. and Sibuga, K. P. (2006). Vignasubterranea (L.) Verdc. In Brink, M. and Belay, G. (Editors). Plant Resources of Tropical African 1. Cereals and pulses. PROTA Foundation, Wageningen, Netherlands. pp. 213-218.

[6] Omoikhoje, S. O. (2008). Assessment of the Nutritive Value of Bambara groundnut as influenced by cooking time. Livestock Research for Rural Development. 20(4).

[7] Adu-Dapaah, H. K. and Sangwan, R. S. (2004). Improving bambara groundnut productivity using gamma irradiation and in-vitro techniques. African Journal of Biotechnology 3(5): 260-265.
[8] Bamishaiye, O. M., Ajebola, J. A and Bamishaiye, E. I. (2011). Bambara groundnut; an underutilized nut in Africa. Advances in Agricultural Biotechnology. 1:60-72.

[9] Olapade, A. and Adetunji, D. O. (2007). Comparison of different methods of producing bambara (Voandzeia subterranean L. Thou) flours for preparation of 'moinmoin' Nigerian Food Journal, 25(2).

[10] Olayiwola, I., Folaranmi, F., Abdul-Rasaqi, A., Oluseye, O., Ajoke, A andWasiu, A. (2013). Chemical, Mineral composition and Sensory acceptability of cocoyam-based recipes enriched with cowpea flour. African Journal of Food and Nutrition, 13: 228-234.

[11] AOAC. (2005). Official Methods of Analysis. Association of Official Analytical Chemists, 18th Edn. Washington D.CUSA.

[12] Egounlety, M., and Aworh, D. C. (1990). Production and physicochemical properties of Tempeh fortified maize based weaning food. Nigerian Food Journal. 70:92-102.

[13] Spackman, D. H., Stein, W. H., Moore, S. (1958). Analytical Chemistry. 30(7): 1190-1206.

[14] Iwe, M. O. (2002). Handbook of sensory methods and analysis. Rojoint Communication Services Ltd., Enugu, Nigeria.

[15] Adebayo-Oyetoro, A. O., Olatidoye, O. P., Ogundipe., F. O, Ogundipe, O. O, Balogun, O. I, Bamidele, F. A and Faboya, A. O. (2011). Evaluation of perioxide composition and functional properties of ofada rice (oryza sativa) flour blended with bambara groundnut (Vigna subterranean L). Journal of Agriculture and Veterinary Sciences, 3, 60-66.

[16] Ogundele, G. F, Ojubanire, B. A and Bamidele, O. P (2014). Evaluation of various characteristics of akara (fried beans cake) made from cowpea (vignaunguiculata) and soybean (glycine max) blends. Journal of Experimental Biology and Agricultural Sciences. Vol. 2 (5).

[17] Sunful, R. E, Sadik. A, Darko, S. (2010). Nutritional and Sensory analysis of soybean and wheat flour composition cake. Pakistan Journal of Nutrition 9:794-796.

[18] Dixit, A. K, Anthony, J. I. X, Sharma, N. K, Tiwari R. K (2011). Soybean consistent and their functional benefits, In: Tiwari V. K, Mishra B. B. (Eds) Opportunity, challenge and scope of natural products in Medicinal Chemistry, Research Signpost Publication, Kerala, India pp. 367-383.

[19] Temple, V, J., Badamosi, E. J., Ladeji, O. and Solomon, M. (1996). Proximate, chemical composition of three locally foundamental complementary foods. West African J. F Biol.Sci.5:134-143.

[20] Baryeh, E. A. (2001). Physical properties of bambara groundnuts, Journal of Food Engineering. 407:321-326.

[21] Oyeleke, G. O., Afolabi, O and Isola, A. D (2012). Some quality characteristics and carbohydrate fractions of bambara groundnut seed flour. IOSR Journal of Applied Chemistry. 2(4):16-18.

[22] Ayo, J. A., Popoola, C. A., Ayo, V. A and Andrew, E. (2013). Effect of added bambara groundnut flour on the quality of acha based fura. British Journal of Applied Science and Technology 4(1):168-176. 
[23] Anitia, B. S., Akpan, E. J., Okon, P. A. and Umoren, I. U. (2006). Nutritive and anti-nutritive evaluation of sweet potatoes (Ipomoea batatas) leaves: Pakistan Journal and nutrition: 5(2):166-168.

[24] Wardlaw, G. M. and Kkessel. M. (2002). Water and major minerals. Perspective in nutrition. ( $5^{\text {th }}$ ed.) p 453.

[25] Oliveira, J.S. (1976). Grain legumes of Mozambique; Tropical Grain Legume Bulletin, 3:13-15.

[26] Oluyemi, J. A., Fetuga, B. L. and Endeley, H. N. L. (1976). The metabolizable energy value of some feed ingredients for young chicks. Poultry Science 55:11-618.

[27] Ijarotimi, O. S. (2008). Nutritional composition, microbial status, functional and sensory properties of infant diets formulated from cooking banana fruits (Musa spp. ABB genome) and fermented bambara groundnut (Vigna subterranean L. Verdc) seeds. Nutrition and Food Science 38 (4): 325-340.

[28] Kure, O. A., Bahago, E. J and Daniel, E. A. (1998). Studies on the proximate composition and effect of flour size of acceptability of biscuits produced from blends of soybeans and plantain flour. Journal of Nematoda Technical Scope. (2): $17-22$.

[29] Jimoh, K. O and Olatidoye, O. P. (2009). Evaluation of Physicochemical and rheological characteristics of soybean fortified yam flour Journal of Applied Bioscience. 13:703-706

[30] FAO. (2000). Production Yearbook, Volume 55, Collection FAO Statistics, no. 170. FAO, Rome, Italy.

[31] Abdulsalami, M. S., Sheriff, H. B. (2010). Effect of processing on the proximate composition and mineral content of bambara groundnut (Voandzeiasubterrenea). Bayero Journal of Pure and Applied Science, 3:188-190.

[32] Udensi, E. A., Oselebe, H. O. and Iweala, O. O. (2008). The investigation of chemical composition and functional properties of water yam (Dioscoreaalata): Effect of varietal differences. Pakistan Journal of Nutrition 7: 342-344.

[33] Faustina, D. W. M., Ibok, O., William, O. E., Robert, A and Bussie, M. D. (2013). Potential health benefit of water yam (Discoreaalata). Food Function. 4: 1496-1501.

[34] Fashakin, J. B., Awoyefa, M. B and Furst, P. (1986). The application of protein concentrates from locally available legumes in development of weaning foods. Ernahrungwisse, 25:220-7.

[35] Wasiu. A., Busie, M., Lateef, O. S, and Taofik, A. S. (2016). Effect of water yam (discoreaalata) flour fortified with distiller's spent grain on nutritional, chemical, and functional properties. Food Science and Nutrition; 4(1): 24-33.

[36] Olapade, A. A. and Akinyanju, F. T. (2014). Chemical and Functional Properties and Performance of Blends of Water Yam (DioscoreaAlata) and (Ojojo) Production. American Journal of Chemistry. 4(3): 89-96.

[37] Lowell, D., Kesi, B., Racquel, W., Mitchelle, O., Sannette, H. and Helen, A. (2012). Antioxidants, minerals and bioactive compounds in tropical staples. African Journal of Food Science and Technology. 3(4): 90-98.

[38] Kandawire Ceasar. (2007). Review of bambara groundnut (Vigna subterranean (L.) Verdc. Production in sub-sahara Africa. Agricultural journal 2 (4): 465-470. 